
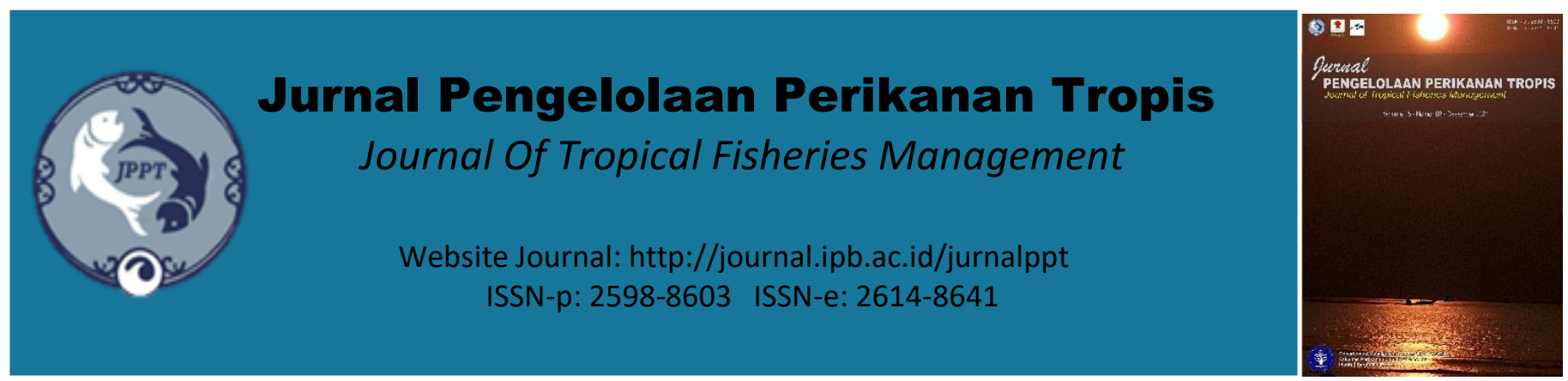

\title{
Pendekatan Ekosistem Pada Pengelolaan Perikanan Tongkol Skala Kecil Melalui Penilaian Domain Teknik Penangkapan Ikan Di Perairan Bali Timur
}

\author{
(An Ecosystem Approach to Small-Scale Cob Fishery Management through the Assessment of the Fishing \\ Technique Domain in East Bali Waters)
}

\author{
Roni Adi Samba ${ }^{1, *}$, Ni Luh Watiniasih ${ }^{2}$, Made Ayu Pratiwi ${ }^{1}$ \\ ${ }^{1}$ Program Studi Manajemen Sumberdaya Perairan, Fakultas Kelautan dan Perikanan, Universitas Udayana. \\ ${ }^{2}$ Program Studi Biologi, Fakultas Matematika dan Ilmu Pengetahuan Alam, Universitas Udayana.
}

\section{INFO ARTIKEL}

\section{Histori Artikel}

Recevied: 29 Mei 2021

Accepted: 28 September 2021

\section{Kata Kunci:}

EAFM, pengelolaan perikanan, teknik penangkapan ikan, ekosistem, tongkol. Keywords:

EAFM, fiheries management, fishing techniques, ecosystem, frigate tuna.

\begin{abstract}
ABSTRAK
Potensi perikanan Karangasem sangat besar dikarenakan terdapat banyaknya sebaran kawasan perikanan tangkap skala kecil di sepanjang wilayah pesisir pantai Karangasem. Tujuan penelitian ini adalah untuk melihat kondisi perikanan tangkap tongkol sekala kecil melalui status domain teknink penangkapan Ikan yang mengacu pada Pengelolaan Perikanan Berpendekatan Ekosistem (EAFM). Berdasarkan hasil perhitungan nilai komposit, status domain teknik penangkapan ikan di Desa Seraya Timur memperoleh skor 68,62. Hasil tersebut mengindikasikan bahwa status EAFM domain teknik penangkapan ikan di Desa Seraya Timur tergolong kategori baik. Namun dari hasil penilaian tersebut masih terdapat dua indikator yang berstatus buruk. Hal ini disebabkan pada penilaian indikator modifikasi alat tangkap $>50 \%$ hasil tangkapan ikan nelayan di Desa Seraya Timur berukuran dibawah Lm. Dan pada indikator Kapasitas Perikanan dan Upaya Penangkapan menunjukan kondisi yang telah overcapacity
\end{abstract}

\section{ABSTRACT}

Karangasem's fishery potential is very large due to the large distribution of small-scale cathing fisheries areas along the coastal areas of Karangasem. The purpose of this study was to see the condition of small-scale tuna fisheries through the status of the fishing domain which refers to the Ecosystem Approach Fisheries Management (EAFM). Based on the results of the calculation of the composite value, the domain status of fishing techniques in East Seraya Village obtained a score of 68.62. These results indicate that the EAFM status of the fishing technique domain in East Seraya Village is categorized as good. However, from the results of the assessment, there are still two indicators that have bad status. This is due to the assessment of indicators of modification of fishing gear $>50 \%$ of fish catches of fishermen in East Seraya Village are under Lm. And the indicators of Fishery Capacity and Catching Efforts show conditions that have been overcapacity.

\section{PENDAHULUAN}

Karangasem merupakan kabupaten yang terletak di ujung paling timur Pulau Bali. Secara astronomis, kabupaten ini berada pada posisi $8^{0} \mathrm{dan}$ $115^{0}$ yang membuatnya beriklim tropis layaknya wilayah lain di Provinsi Bali. 00 '00 - 841 '37,8 Lintang Selatan, 35'9,8 - 11554 '8,9 Bujur Timur. Badan Pusat Statistik (BPS) Kabupaten Karangasem (2016) menyatakan bahwa potensi minapolitan yang berupa produksi perikanan laut/perikanan tangkap di Kabupaten Karangasem mencapai 18.378,24 ton/tahun. Nilai produksi mencapai Rp. 164.565.436.000,00 dengan hasil tangkapan terbesar ada pada jenis ikan tongkol. Sedangkan menurut data Dinas Kelautan dan Perikanan (DKP) Provinsi Bali (2018) bahkan pada tahun tersebut jumlah produksi hasil tangkapan mencapai 21.534,5 ton/tahun.

Potensi perikanan Karangasem sangat besar dikarenakan terdapat banyaknya sebaran Kawasan 
perikanan tangkap skala kecil di sepanjang wilayah pesisir pantai Karangasem. Salah satunya adalah kawasan perikanan tangkap di Desa Seraya Timur. Desa yang terletak di Kecamatan Karangasem ini memiliki potensi kelautan dan perikanan yang cukup besar khususnya ikan tongkol yang merupakan salah satu ikan target tangkapan utama nelayan. Berdasarkan ciri-cirinya selama observasi kawasan Perikanan tangkap di Desa Seraya Timur termasuk kedalam perikanan tangkap skala kecil (small-scale fisheries). Hal ini sebagaimana yang disampaikan FAO (2015) bahwa ciri-ciri smallscale fisheries yaitu memiliki modal investasi kecil, sarana perahu kecil, wilayah operasi penangkapan tidak terlalu jauh, dan hasil tangkapan untuk kebutuhan konsumsi.

Hasil observasi di lapangan juga menunjukan data produktivitas penangkapan (panen) ikan tongkol tahun 2019 sudah terjadi sejak bulan Juli. Hal ini sejalan dengan Ilhamdi (2016) yang menyatakan bahwa musim penangkapan ikan tongkol terjadi yaitu pada bulan Juli, Agustus, September, Oktober dan November. Besar kecilnya perolehan hasil tangkapan dipengaruhi beberapa faktor, diantaranya penentuan fishing ground, jenis alat tangkap, ukuran kapal, dan cara pengoperasian alat tangkap.

Penjelasan diatas menunjukan bahwa pada Kawasan perikanan tangkap tongkol skala kecil dewasa ini penting untuk dilaksanakan pengelolaan pemanfaatan sumber daya ikan yang berkelanjutan. Sebagaimana diamanahkan di dalam UU No.45 Tahun 2009 tentang Perikanan yang dilakukan berdasarkan asas manfaat, keadilan, kemitraan, pemerataan, keterpaduan, keterbukaan, efisiensi, dan kelestarian yang berkelanjutan.
Kompleksitasnya kepentingan dan pemanfaatan sumberdaya perikanan tersebut dirasakan sangat mendesak perlunya model/pendekatan khususnya dalam pengelolaan perikanan tangkap di karangasem. Pendekatan yang paling mungkin dilakukan saat ini adalah Pengelolaan Perikanan Berpendekatan ekosistem (Ecosystem Approach to Fisheries Management) yang selanjutnya disingkat EAFM.

Berdasarkan latar belakang tersebut maka perlu dilakukan penelitian terkait kondisi perikanan tangkap tongkol sekala kecil melalui Status Domain Penangkapan Ikan yang mengacu pada Pengelolaan Perikanan Berpendekatan Ekosistem (EAFM). Selain itu penelitian ini juga bertujuan untuk mengetahui pemetaan atau pola daerah tangkapan (fishing ground) ikan tongkol di Desa Seraya Timur; untuk mengetahui proses atau teknik penangkapan ikan yang dilakukan nelayan di Desa Seraya Timur; dan yang terutama adalah untuk keberlanjutan perikanan di Desa Seraya Timur maka perlu dilakukan penilaian terhadap status domain teknik penangkapan ikan dengan pendekatan ekosistem (EAFM).

\section{METODE}

\section{Waktu dan Tempat}

Penelitian ini dilakukan di Desa Seraya Timur, tepatnya di Pantai Bias Lantang dengan letak geografis $8^{\circ} 26^{\prime} 03^{\prime \prime} 0$ Lintang Selatan dan $115^{\circ} 41^{\prime} 02.1$ " Bujur Timur Kecamatan Karangasem, Kabupaten Karangasem, Bali (Gambar 1). Penelitian ini dilaksanakan selama dua bulan, dari bulan November hingga bulan Desember tahun 2019.

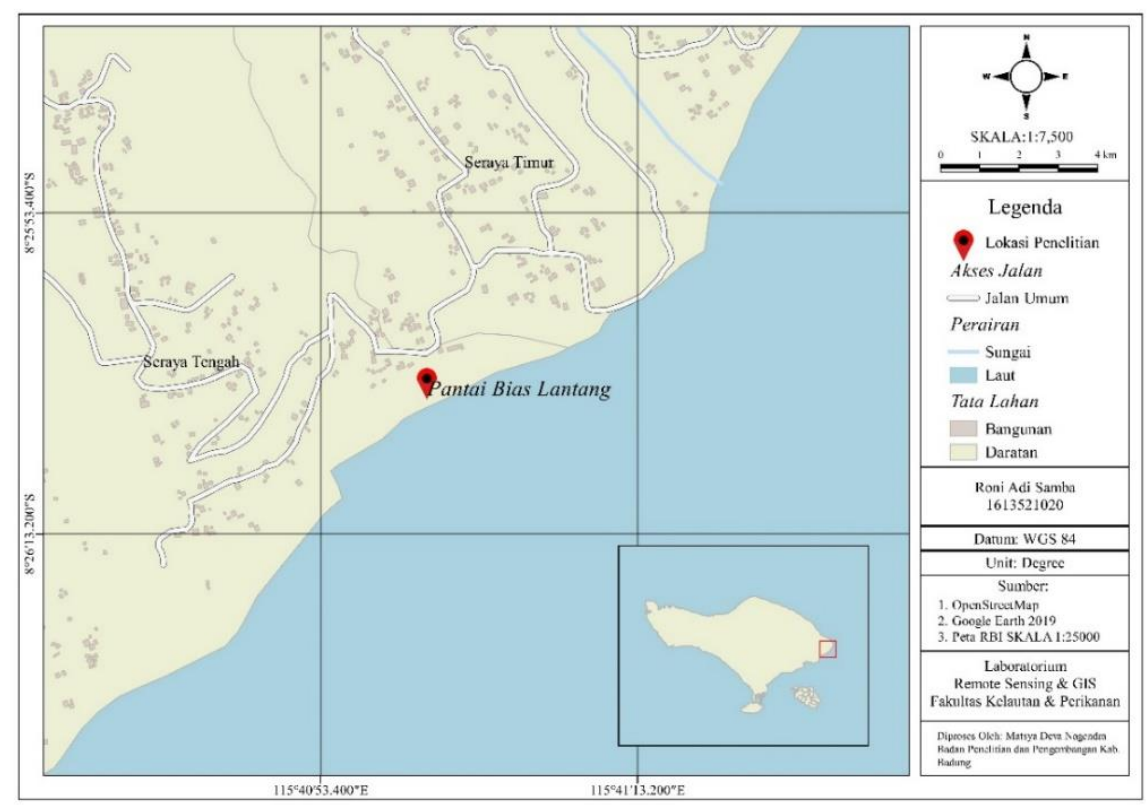

Gambar 1. Peta lokasi penelitian 


\section{Alat dan Bahan}

Alat dan bahan yang digunakan adalah worksheet, handcounter, penggaris, kamera, alat tulis, GPS, perahu, alat tangkap ikan, dan ikan tongkol (Auxis thazard).

\section{Metode Penelitian}

Penelitian ini dilakukan dengan menggunakan data primer dan sekunder. Pengumpulan data primer mengacu kepada Modul EAFM yang dikeluarkan oleh KKP tahun 2014. Pengambila data primer dilakukan dengan metode survey melalui pengamatan dan pengukuran langsung dan menggunakan metode purposive sampling, dengan mengikuti langsung proses berlayar sesuai alur penangkapan ikan yang dilakukan oleh nelayan Desa Seraya Timur selama dua bulan (November dan Desember). Frekuensi pengambilan data primer dilakukan dengan kegiatan operasi penangkapan ikan (trip) yaitu sebanyak 8 kali. Selain itu pengambilan data primer dilakukan dengan mengikuti alur penentuan daerah tangkapan ikan (fishing ground) yang ditentukan oleh nelayan secara tradisional dan mengamati teknik pengoprasian alat penangkap ikan. Sedangkan untuk data sekunder yaitu diolah dari statistik perikanan tangkap yang diperoleh dari Dinas Kelautan dan Perikanan Provinsi Bali periode lima tahun terakhir.

\section{Penentuan Daerah Tangkapan Ikan (Fishing Ground)}

Pada penentuan Daerah Tangkapan Ikan dilakukan dengan mengikuti alur pelayaran dan proses penangkapan ikan di fishing ground kemudian mencatat semua titik koordinat masingmasing 4 titik pada setiap fishing ground (lintang dan bujur). Ke-4 titik tersebut merupakan titik pelampung pertama dan kedua saat setting dantitik pelampung pertama dan kedua saat penarikan jaring atau hauling. Pengamatan titik menggunakan GPS saat mengikuti proses penangkapan di atas perahu. Kemudian data dikumpulkan beserta jumlah atau kelimpahan hasil tangkapan ikan pada setiap titik operasi penangkapan.

Pengambilan data adalah berupa hasil pengamatan terkait teknik pengoprasian alat dan penangkapan ikan yang dilakukan oleh nelayan dari mulai persiapan awal sebelum perahu melaut hingga melakukan proses penangkapan ikan di fishing ground. berupa penggunaan alat tangkap, dampak penggunaan alat tangkap terhadap lingkungan, menghitung jumlah hasil tangkapan (ikan target) dan bycath. Perahu yang digunakan adalah kapal yang memiliki dimensi panjang $6 \mathrm{~s} / \mathrm{d}$
6,5 meter, lebar 0,4 s/d 0,5 meter, dan dalam 0,7 s/d 1 meter. Alat tangkapnya jaring insang permukaan sepanjang 500 s/d 600 meter dan lebar 3 meter. Perahu memiliki alat penggerak layar dan motor tempel berkapasitas 15 PK (Tenaga Kuda).

\section{Domain Teknik Penangkapan Ikan pada EAFM}

Pengumpulan data menggunakan metode survey/wawancara dengan purposive sampling. Pada metode survey/wawancara, peneliti melakukan pengamatan dari indikator-indikator pada domain teknik penangkapan ikan pada EAFM. Pada metode purposive sampling, nelayan dan kapal yang dipilih secara acak dari kelompok nelayan yang berbeda-beda. Kemudian jumlah ikan yang diukur yaitu menyesuaikan hasil tabgkapan ikan/trip. Pada domain teknik penangkapan ikan EAFM terdapat 6 indikator, akan tetapi peneliti hanya menggunakan 4 indikator. Hal ini dikarenakan dua indikator lainnya tidak relevan digunakan di ruang lingkup penelitian yang hanya termasuk pada perikanan skala kecil. Dari keempat indikator tersebut memiliki perbedaan pengumpulan data pada Tabel 1. Dari keempat indikator pada Tabel 1, beberapa data yang diperlukan pada saat melakukan penelitian yaitu pada Tabel 2.

Peniaian indikator EAFM yang digunakan yaitu merupakan sistem multikriteria yang berujung pada indeks komposit terkait dengan tingkat pencapaian pengelolaan perikanan sesuai dengan prinsip EAFM yang disajikan dengan dua jenis "tools" yang digunakan untuk mengubah indikator parsial menjadi indikator komposit yaitu teknik Flag Modeling.

\section{Analisis Data}

\section{Penentuan Daerah Tangkapan Ikan (Fishing Ground)}

Analisis data yang dilakukan yaitu dengan mengagambarkan pola daerah tangkapan ikan (fishing ground) dengan mengolah data berdasarkan titik koordinat (lintang dan bujur) di tiap titik fishing ground yang diperoleh dari hasil observasi. Data yang berupa titik koordinat tersebut dianalisis dan diolah menggunakan pemerograman software GIS dengan melalui Optimized Hotspot Analysis pada aplikasi QGIS 2.8 .

Indikator metode penangkapan ikan yang bersifat destruktif dan/atau illegal

Pada penilaian indikator ini dilakukan dengan melihat jumlah kasus pelanggaran yang dilakukan oleh nelayan di Desa Seraya Timur pada saat melakukan penangkapan di Perairan Bali Timur. Dalam penggunaannya indikator ini mengacu pada 
pelanggaran penggunaan ala tangkap yang bersifat destruktif dan atau illegal yang dilakukan oleh nelayan Desa Seraya Timur selama penelitian. Selanjutnya peneliti juga mengamati jika terjadi penangkapan ikan pada zona atau kawasan konservasi di wilayah perairan Bali Timur. Semakin sedikit kasus yang terjadi maka nilai skor semakin tinggi.

\section{Indikator modifikasi alat penangkapan ikan dan alat bantu penangkapan ikan}

Pada indikator penilaian dilakukan dengan membandingkan rata-rata ukuran ikan target yang tertangkap dengan ukuran $L m$ ikan target tersebut. Semakin sedikit ikan target yang berukuran $<L m$ maka nilai skor semakin tinggi.

\section{Indikator Kapasitas Perikanan (Fishing Capacity) dan Upaya Penangkapan (Effort)}

Pada penilaian indikator ini dilakukan dengan melihat nilai rasio (R) dari perbandingan fishing capacity pada tahun dasar (tahun sebelumnya) dengan fishing capacity pada tahun terakhir. Semakin tinggi nilai $\mathrm{R}$ maka nilai skor semakin tinggi. Fishing capacity ditentukan dengan cara menghitung perkalian antara jumlah kapal (unit) dengan hasil tangkapan maksimum (ton) dan jumlah effort (trip) setiap tahun selama 6 tahun terakhir (NWG EAFM, 2014):

\section{Fishing Capacity, $F C=V \times C \times E$}

\section{Dimana:}

$\mathrm{FC}=$ Kapasitas perikanan (fishing capacity),

$\mathrm{V}=$ Jumlah kapal (unit),

$\mathrm{C}$ = Jumlah hasil tangkapan (ton), dan

$\mathrm{E}=$ Upaya penangkapan (trip).

\section{Indikator Selektivitas Alat Tangkap}

Pada penilaian indikator ini dilakukan dengan melihat jumlah penggunaan alat tangkap yang selektif. Semakin banyak jumlah alat tangkap selektif maka nilai skor semakin tinggi. Tinggi atau rendahnya selektivitas penangkapan dianalisis dengan melihat jenis alat tangkap yang digunakan sesuai dengan daftar penggolongan selektivitas alat tangkap yang ada serta menghitung jumlah tangkapan utama berbanding hasil tangkapan sampingan.

$$
\frac{\text { jumlah tangkapan utama }}{\text { jumlah tangkapan sampingan }} \times 100 \%
$$

Semakin tinggi persentase hasil tangkapan utama dibandingkan hasil tangkapan sampingan maka alat tangkap tersebut semakin selektif. Semakin selektif alat tangkapnya maka ancaman terhadap kerusakan ekosistemnya semakin kecil.

Tabel 1. Pengumpulan data indikator domain teknik penangkapan ikan

\begin{tabular}{cll}
\hline No & \multicolumn{1}{c}{ Indikator } & \multicolumn{1}{c}{ Pengumpulan Data } \\
\hline 1 & Metode penangkapan ikan yang destruktif & Survey dan pengamatan langsung dengan ikut melaut \\
dan/atau illegal & bersama nelayan, serta mencatat koordinatnya \\
2 & $\begin{array}{l}\text { Modifikasi alat penangkapan ikan dan alat } \\
\text { bantu penangkapan }\end{array}$ & $\begin{array}{l}\text { Survey dan pengamatan langsung saat ikut melaut serta } \\
\text { melakukan wawancara }\end{array}$ \\
3 & Kapasitas perikanan dan upaya penangkapan & $\begin{array}{l}\text { Mencari data sekunder di Dinas Perikanan setempat dan } \\
\text { wawancara terhadap nelayan }\end{array}$ \\
4 & Selektivitas alat tangkap & Survey dan pengukuran ikan dengan purposive sampling \\
\hline
\end{tabular}

Sumber: NWG EAFM (2014)

Tabel 2. Data yang diperlukan pada setiap indikator domain teknik penangkapan ikan

\begin{tabular}{cll}
\hline No & \multicolumn{1}{c}{ Indikator } & \multicolumn{1}{c}{ Data } \\
\hline 1 & $\begin{array}{l}\text { Metode penangkapan ikan yang destruktif } \\
\text { dan/atau illegal }\end{array}$ & $\begin{array}{l}\text { Jumlah pelanggaran yang dilakukan pada nelayan dalam 1x } \\
\text { trip }^{(\mathrm{P})}\end{array}$ \\
$\begin{array}{l}\text { Modifikasi alat penangkapan ikan dan alat } \\
\text { bantu penangkapan }\end{array}$ & $\begin{array}{l}\text { - Panjang ikan saat pertama kali matang gonad }(\mathrm{Lm})^{(\mathrm{P})} \\
\text { - Panjang ikan yang dominan tertangkap dalam satu trip }{ }^{(\mathrm{S})}\end{array}$ \\
& Kapasitas perikanan dan upaya penangkapan & $\begin{array}{l}\text { - Jumlah hasil tangkapan ikan }{ }^{(\mathrm{P})} \\
\text { - Jumlah kapal penangkap ikan }{ }^{(\mathrm{S})}\end{array}$ \\
& Selektivitas alat tangkap & $\begin{array}{l}\text { - Jumlah trip kapal penangkap ikan }{ }^{(\mathrm{S})} \\
\text { Jumlah ikan yang tertangkap dan jenis alat penangkapan ikan } \\
\text { (P) }\end{array}$ \\
\hline
\end{tabular}

Sumber: NWG EAFM (2014) 


\section{Analisis penilaian indikator EAFM domain teknik penangkapan ikan}

Penilaian indikator pada domain ini menggunakan skor likert ordinal 1,2,3 sesuai dengan kriteria penilaian masing-masing indicator. Kriteria penilaian telah ditetapkan dengan mengacu pada modul NWG EAFM Ditjen SDIKKP RI (2014). Nilai indeks diperoleh dengan cara mengalikan nilai skor dengan bobot setiap indikator. Pembagian bobot untuk setiap indikator ditentukan berdasarkan derajat pengaruh (tingkat kepentingan) indikator tersebut di dalam domain Indikator yang memiliki pengaruh langsung atau pengaruh yang besar dalam domain, maka indikator tersebut memiliki bobot yang besar pula. Tabel 3 merupakan tabel penilaian bobot dan visualisasi dalam bentuk model bendera yang merupakan analisis yang digunakan menurut NWG EAFM Ditjen-SDI KKP (2014). Berikut alur analisis data penilaian Indikator EAFM pada Gambar 2.

\section{Nilai Indeks, Cat- $i=$ Sat-i $x$ Wat $-I$}

Dimana $\mathrm{C}_{\mathrm{at}-\mathrm{i}}=$ Nilai indeks atribut/indikator ke-i, $\mathrm{S}_{\mathrm{at}-\mathrm{i}}=$ skor atribut/indikator ke-I, $\mathrm{W}_{\mathrm{at}-\mathrm{i}}=$ bobot atribut/indikator ke-i.

Total nilai indeks yang diperoleh, selanjutnya dianalisis dengan menggunakan analisis komposit sederhana berbasis rataan aritmetik. Hasil nilai komposit tersebut akan ditampilkan dalam bentuk model bendera (flag model) sesuai Tabel 4. Nilai komposit ini merupakan konversi nilai dari total semua indikator.

$$
\text { Nilai Komposit, } N K=\left(C_{a t} / C_{a t-m a x}\right) \times 100
$$

Dimana $\mathrm{C}_{\mathrm{at}}=$ Nilai indeks total semua atribut atau indikator, $\mathrm{C}_{\mathrm{at}-\mathrm{max}}=$ Nilai indeks total maksimum.

\section{HASIL DAN PEMBAHASAN}

\section{Hasil}

\section{Gambaran Umum Kondisi Perikanan Tangkap di Desa Seraya Timur}

Kegiatan penangkapan yang dilakukan di Desa Seraya Timur menggunakan armada penangkapan berukuran kurang dari 5 GT dengan mesin motor tempel. Mesin yang digunakan bermerk Yamaha dan juga Suzuki dengan kekuatan 15 PK. Bahan dari kapal jukung terbuat dari fiber dengan ukuran panjang $6-6,5 \mathrm{~m}$, lebar $0,4-0,5 \mathrm{~m}$, dan tinggi $0,7-$ $1 \mathrm{~m}$ yang dimiliki oleh nelayan secara perorangan. Dalam 1 perahu biasanya diisi oleh 1 atau 2 orang nelayan. Alat tangkap yang digunakan oleh nelayan adalah jaring insang (gillnet) dan pancing ulur.

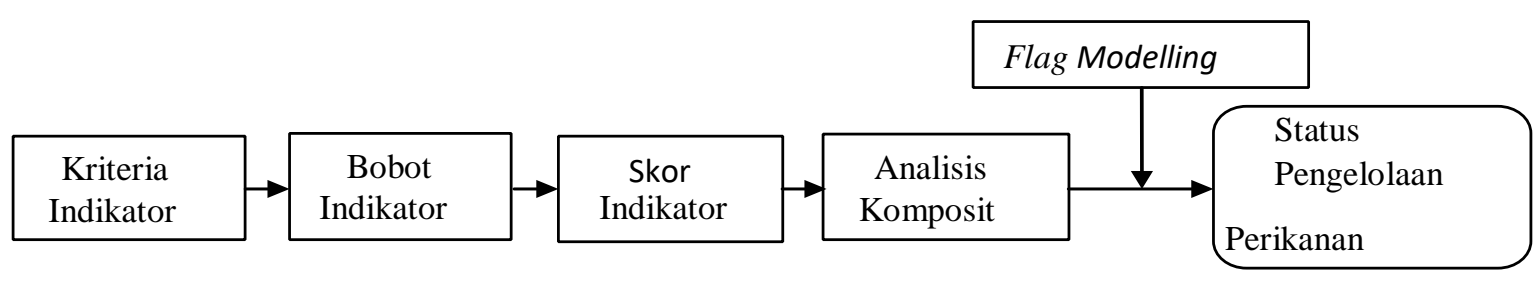

Gambar 2. Alur Analisis Penilaian Indikator EAFM

Tabel 3. Penilaian bobot pada indikator domain teknik penangkapan ikan

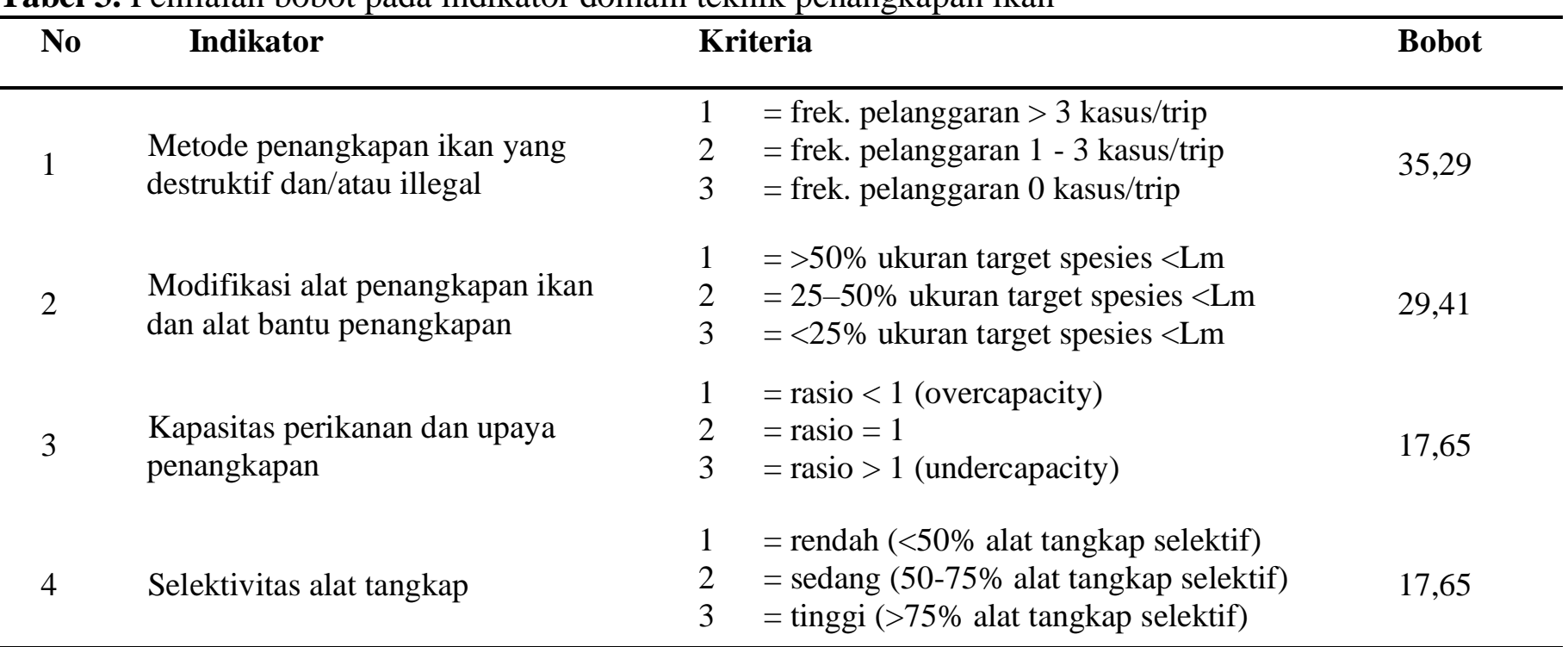


Sumber: NWG EAFM (2014)

Tabel 4. Visualisasi model bendera untuk indicator EAFM

\begin{tabular}{ccc}
\hline Nilai Skor Komposit & Model Bendera & Deskripsi \\
\hline $1-20$ & & Buruk \\
$21-40$ & Kurang Baik \\
$41-60$ & Sedang \\
$61-80$ & Baik \\
$81-100$ & Baik Sekali \\
\hline
\end{tabular}

Sumber: NWG EAFM (2014)

Lokasi penangkapan terletak disekitar perairan Karangasem sampai ke Selat Lombok. Sistem penangkapan yang dilakukan oleh nelayan adalah one day fishing dengan waktu keberangkatan pukul 04.00-09.00. Komoditas tangkapan utama nelayan adalah ikan tongkol krai (Auxis thazard) atau nelayan lokal menyebutnya dengan sebutan pindang awan. Namun, selain ikan tersebut nelayan juga sering mendapatkan ikan cakalang.

Nelayan di Desa Seraya Timur memproleh ikan hasil tangkapan sampingan yang tergolong spesies ETP yaitu seperti penyu hijau dan lumba-lumba. Penyu hijau dan lumba-lumba termasuk hasil bycatch sehingga ketika nelayan mendapatkan kedua spesies tersebut nelayan akan langsung melepaskannya agar melestarikan kedua spesies tersebut. Berdasarkan pengalaman nelayan penyebab tersangkutnya penyu hijau dan lumbalumba di jaring nelayan adalah karena kedua spesies tersebut memakan ikan tongkol yang terjerat di nelayan sehingga mereka juga ikut tersangkut di jaring.

Produksi ikan tongkol krai di Kabupaten Karangasem selama 6 tahun terakhir mengalami fluktuasi (Tabel 5). Berdasarkan pengalaman nelayan, beberapa tahun terakhir musim peanngkapan ikan sangat sulit ditentukan. Hal ini diperkirakan karena kondisi alam dan cuaca yang tidak menentu. Hasil tangkapan ikan tongkol krai biasanya dijual oleh nelayan kepada pengepul yang kemudian akan didistribusikan atau dijual oleh penjual di pinggir jalan maupun dikirim ke Kusamba untuk jadikan pindang. Harga ikan tongkol krai di Desa Seraya Timur pada saat musim sedang berada dikisaran Rp.5000-Rp.7000. Sedangkan ketika musim penangkapan ikan dan juga memperoleh hasil yang melimpah, harga per ekornya mencapai Rp. 1000 - Rp.2000.

\section{Daerah Penangkapan Ikan}

Daerah penangkapan ikan yang dilakukan oleh nelayan di Pantai Bias Lantang Desa Seraya yaitu masih tergolong area Selat Lombok yang masih termasuk WPP 573. Penentuan daerah penangkapan ikan yang dilakukan oleh nelayan masih tergolong tradisional hanya dengan naluri dan pertimbangan dari arah arus, angin dan pengalaman penangkapan sebelumnya. Musim penangkapan ikan yang terjadi di Desa Seraya Timur mengalami kelimpahan tinggi pada bulan Juli sampai November tahun 2019, namun menurut nelayan setempat umumnya puncak musim penangkapan di Desa Seraya terjadi pada bulan Agustus sampai Oktober. Meskipun demikian sejak tahun 2019 musim tangkapan hampir terjadi sepanjang tahun. Gambar 3 merupakan peta daerah penangkapan ikan yang dibuat berdasarkan hasil pengolahan dari titik koordinat yang didapatkan selama 8 kali pelayaran (trip). Pada setiap trip terdapat 4 kali pengambilan titik koordinat yang meliputi Titik setting awal, titik setting akhir, titik hauling awal dan titik hauling akhir. Hasil tangkapan tertinggi ditemukan pada pengamatan keempat, sedangkan yang terendah ditemukan pada trip ke enam. Pada pengamatan kedua, ketiga, kelima dan keenam memiliki jarak yang berdekatan.

\section{Indikator metode penangkapan ikan yang bersifat destruktif dan/atau illegal}

Berdasarkan hasil pengamatan indikator ini nelayan di Desa Seraya Timur melakukan penangkapan tidak berada dalam zona atau kawasan konservasi. Selain itu tidak ditemukan penggunaan alat tangkap yang destruktif/ merusak maupun dilarang yang dilakukan oleh nelayan. Penggunaan alat tangkap bersifat ramah lingkungan karena nelayan hanya menggunakan jaring insang dan pancing ulur. Pada indikator metode penangkapan ikan yang destruktif dan/atau ilegal sehingga diperoleh nilai tinggi dengan skor 3. Hal ini dikarenakan tidak terdapatnya kasus 
pelanggaran yang dilakukan oleh nelayan di Desa Seraya Timur.

Tabel 5. Indikator kapasitas penangkapan di Desa Seraya

\begin{tabular}{ccc}
\hline Tahun & $\begin{array}{c}\text { Fishing capacity } \\
(\text { V x C x E) }\end{array}$ & Rasio \\
\hline 2013 & $21.722 .114 .270 .313,6$ & 0 \\
2014 & $13.423 .406 .543 .020,8$ & 1,618 \\
2015 & $28.969 .610 .241 .697,2$ & 0,463 \\
2016 & $20.189 .243 .048 .403,0$ & 1,435 \\
2017 & $12.497 .266 .501 .668,0$ & 1,615 \\
2018 & $22.852 .902 .645 .014,0$ & 0,547 \\
\hline
\end{tabular}

Sumber: Diolah dari data statistik perikanan tangkap (DKP Provinsi Bali Tahun 2013-2018)

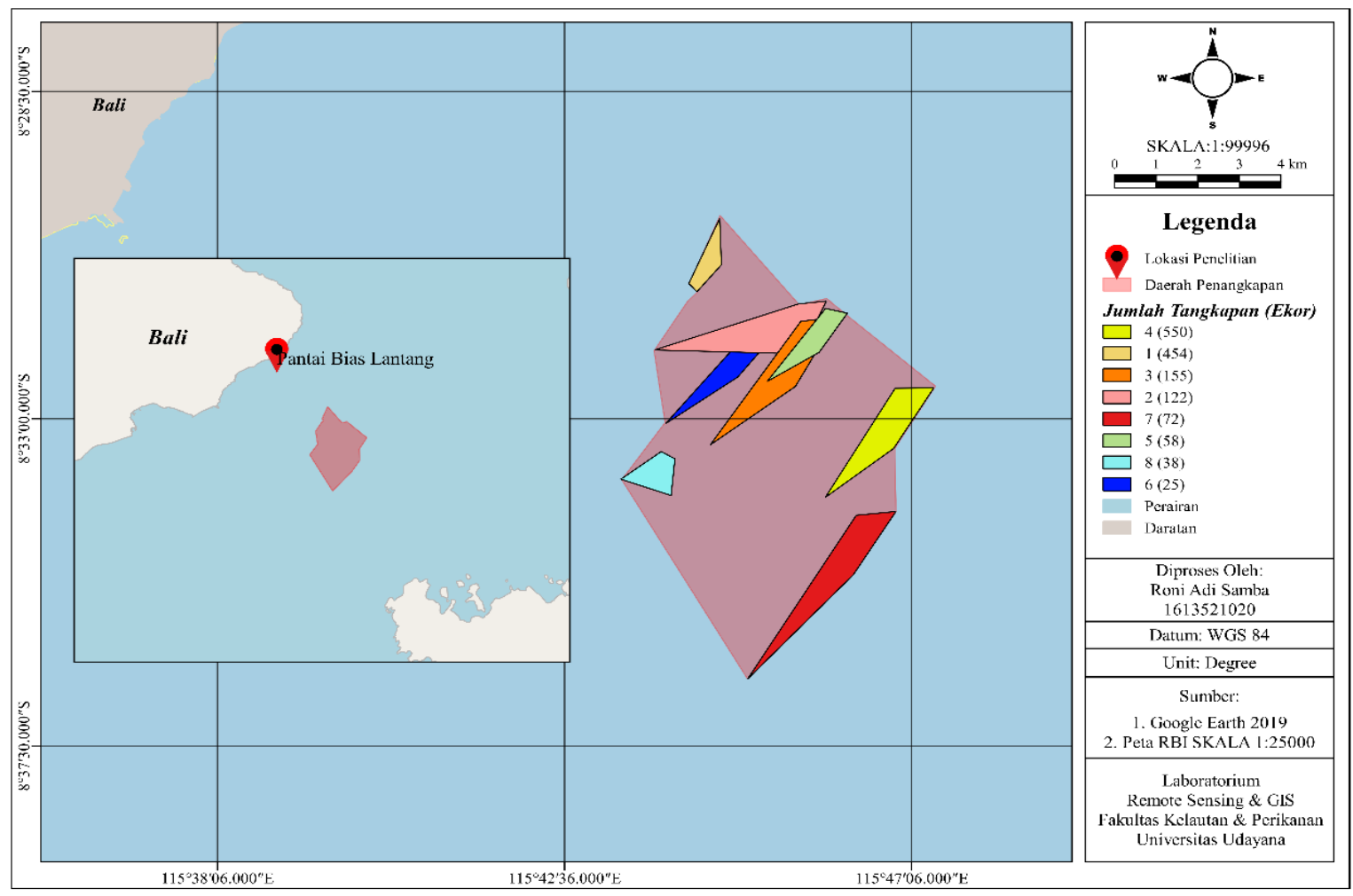

Gambar 3. Peta daerah penangkapan ikan

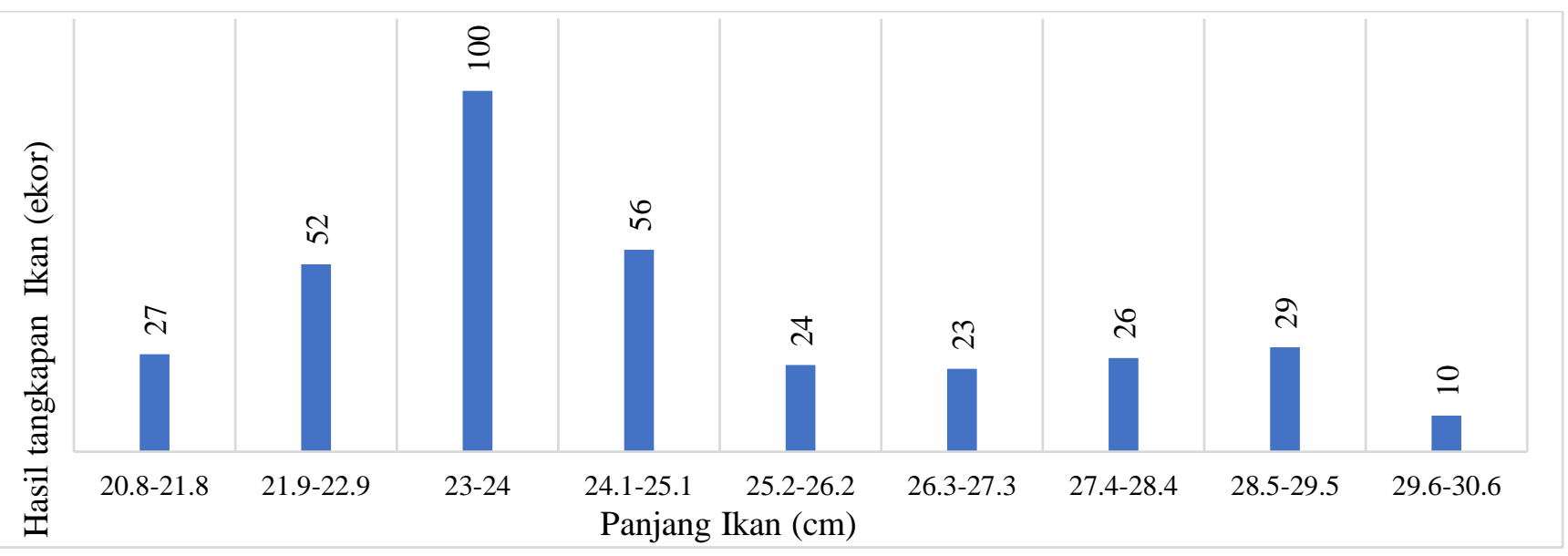

Gambar 4. Grafik Sebaran Panjang Ikan Tongkol Krai (Auxis thazard)

Indikator modifikasi alat penangkapan ikan dan alat bantu penangkapan ikan
Hasil pengamatan dan wawancara menunjukkan bahwa nelayan tersebut masih 
menggunakan alat tangkap sesuai dengan PERMEN-KP No.71 Tahun 2016. Berdasarkan modul NWG EAFM Ditjen SDI-KKP RI (2014), indikator ini dinilai secara tidak langsung dengan membandingkan rata-rata ukuran ikan target yang tertangkap dengan ukuran $L m$, sedangkan jumlah ikan tongkol krai yang diukur sebanyak 347 ekorBerdasarkan hasil penilaian pada indikator menunjukan warna merah yaitu kondisi yang buruk. Akan tetapi secara umum modifikasi alat tangkap yang dilakukan oleh nelayan di Desa Seraya Timur tidaklah berpengaruh terhadap keramah lingkungannya jaring insang itu. Hal ini dikarenakan tidak adanya bahaya pada jaring insang permukaan atau gillnet dengan ukuran panjang 500 meter dan lebar 3 meter dengan ukuran lubang atau mesize 2 inchi. Selain jaring insang permukaan, nelayan setempat juga menggunnakan pancing ulur yang memiliki konstruksi alat tangkap dan sesuai dengan Peraturan Pemerintah yang berlaku. Selain gillnet dan pancing ulur nelayan setempat juga tidak menggunakan alat bantu penangkapan lain seperti rumpon untuk menghadang ruaya gerombolan ikan.

Berdasarkan hasil pengukuran pada semua sample ikan tongkol krai (Auxis thazard) yang ditangkap oleh nelayan di desa Seraya Timur. Menunjukan bahwa ikan yang ditangkap selama periode penelitian diperoleh rata-rata panjang ikan hanya $25,3 \mathrm{~cm}$ (Gambar 4). Dari hasil pengukuran tersebut juga didapatkan tebal badan (body depth) dari ikan tongkol krai. Untuk ukuran ikan diatas $34,8 \mathrm{~cm}$ memiliki body depth sebesar 7,2-7,4 cm. Hasil analysis menunjukkan bahwa $100 \%$ ikan yang diukur memiliki panjang dibawah $L m$ ikan tongkol (belum matang gonad). (Gambar 2) Sedangkan menurut hasil penelitian Jayanti et al, (2020) bahwa Lm ikan tongkol (Auxis thazard) di perairan Bali Timur yaitu $34,8 \mathrm{~cm}$. Sehingga pada penilaian EAFM indikator modifikasi alat penangkapan ikan dan alat bantu penangkapan diperoleh nilai rendah dengan skor 1 . Hal ini dikarenakan hasil tangkapan nelayan tergolong masih kurang layak karena lebih dari 50\% ikan target yang diamati belum mencapai ukuran $\mathrm{Lm}$ nya.

\section{Indikator Kapasitas Perikanan (Fishing Capacity) dan Upaya Penangkapan (Effort)}

Pada indikator kapasitas perikanan (fishing capacity) dan upaya penangkapan secara tidak langsung dinilai dengan cara membandingkan fishing capacity pada tahun dasar (tahun sebelumnya) dengan fishing capacity pada tahun terakhir. Data yang digunakan untuk menghitung fishing capacity adalah jumlah hasil tangkapan ikan, jumlah kapal, dan jumlah trip (upaya penangkapan) dalam kurun waktur tertentu (data 6 tahun terakhir yaitu 2013 - 2018). Sehingga diperoleh rata - rata rasio fishing capacity seperti pada Tabel 6. Hasil analisis fishing capacity memperoleh rasio rata - rata sebesar 0,946 atau berdasarkan modul NWG EAFM, pada indikator ini memdapatkan skor 1 yaitu overcapacity dengan rasio rata-rata $<1$.

\section{Indikator Selektivitas Alat Tangkap}

Penilaian Indikator selektivitas alat tangkap menggunakan analisis data dengan melihat hasil tangkapan dari operasi penangkapan. Hasil disajikan dalam bentuk persentase. Berdasarkan hasil perbandingan proporsi hasil tangkapan dengan alat tangkap jaring insang, memperoleh persentase sebesar 100\% (Gambar 5). Kemudian perbandingan proporsi hasil tangkapan menggunakan pancing ulur adalah 100\% (Gambar 6). Berdasarkan modul NWG EAFM, pada indikator ini diperoleh skor 3 dikarenakan tidak terdapat tangkapan sampingan (bycatch) pada alat tangkap jaring insang maupun pada pancing ulur.

\section{Penilaian EAFM domain teknik penangkapan ikan}

Berdasarkan hasil perhitungan nilai komposit, domain teknik penangkapan ikan di Desa Seraya Timur memperoleh skor 68,62 dengan viasualisasi model bendera berwarna hijau muda (Tabel 7). Hasil tersebut mengindikasikan bahwa domain teknik penangkapan ikan di Desa Seraya Timur tergolong kategori baik. Namun pada 2 indikator yaitu modifikasi alat penangkapan ikan dan alat bantu penangkapan termasuk kategori buruk hal ini dikarenakan seluruh ikan target yang didapatkan masih berukuran dibawah ukuran pertama kali matang gonad $(\mathrm{Lm})$. Sedangkan pada indikator kapasitas perikanan dan upaya penangkapan ikan tergolong kategori buruk yaitu terjadinya overcapacity dalam upaya penangkapan yang dilakukan oleh nelayan di Desa Seraya Timur.

Berdasarkan hasil perhitungan status domain teknik penangkapan ikan didapatkan hasil gambaran bahwa diwilayah perairan Bali Timur, Desa Seraya Timur, Karangasem masih tergelong baik dengan visualisasi flag modeling berwarna hijau seperti pada Gambar 7. Hal ini membuktikan bahwa diwilayah perairan Bali Timur (Desa Seraya Timur, Karangasem) yang berada di WPP-RI 573 menyumbangkan status yang baik meskipun secara nasional menurut data KKP (2011) WPP-RI 573 dinyatakan memiliki status domain teknik penangkapan ikan dalam kondisi buruk dengan flag modeling berwarna kuning muda. 


\section{Pembahasan}

\section{Kegiatan perikanan tangkap tongkol (Auxis thazard) di Desa Seraya Timur}

Kegiatan penangkapan ikan yang dilakukan nelayan di perairan Desa Seraya Timur berada di WPP-RI 573 termasuk kedalam kategori one day fishing. Hal ini karena kegiatan penangkapan dilakukan umumnya cukup singkat mulai dari pukul 04.00 pagi -09.00 siang. Sedangkan perahu yang digunakan yaitu perahu dengan ukuran kurang dari 5 GT. Mesin penggerak yang digunakan oleh nelayan yaitu mesin motor tempel dengan kekuatan 15 PK. Selain itu alat tangkap utama yang digunakan oleh nelayan setempat adalah jaring insang ( gillnet) dan beberapa nelayan juga menggunakan alat tangkap tambahan yaitu pancing ulur.

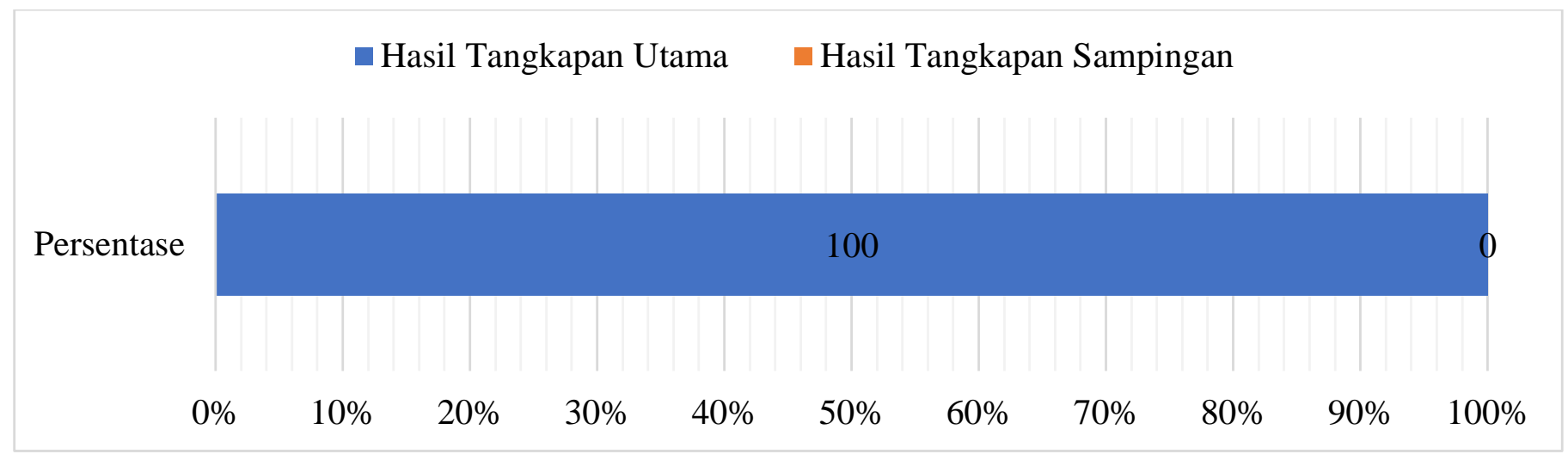

Gambar 5. Proporsi Hasil Tangkapan Utama Tongkol (Auxis thazard) dengan Jaring Insang (gillnet).

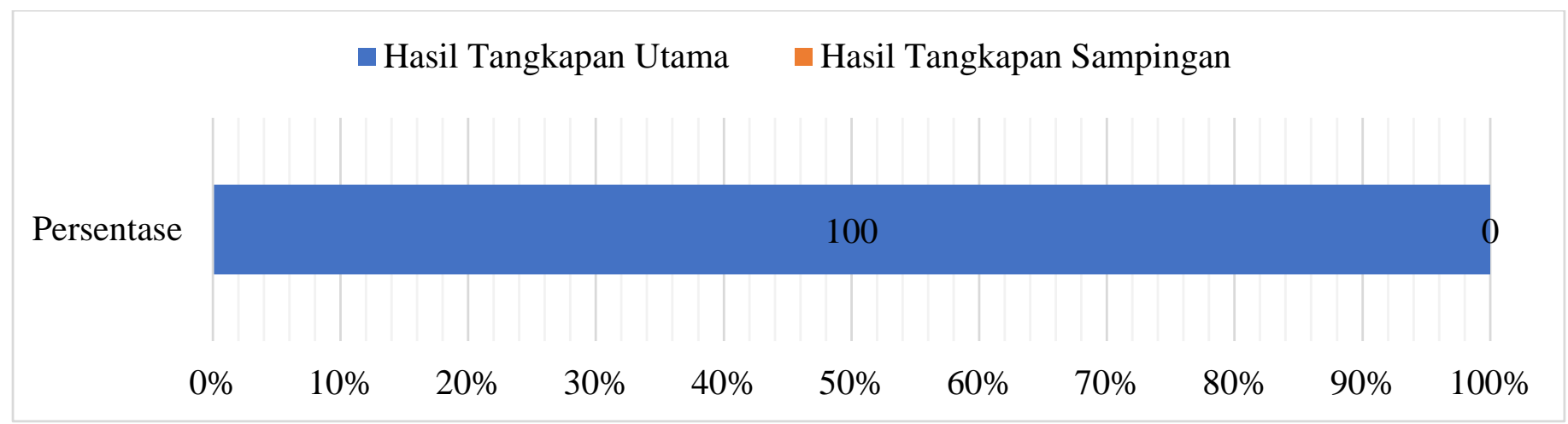

Gambar 6. Proporsi Hasil Tangkapan Ikan Tongkol (Auxis thazard) dengan Pancing Ulur.

Tabel 6. Penilaian EAFM

\begin{tabular}{|c|c|c|c|c|c|c|}
\hline No & Indikator & Kriteria & Skor & Bobot & $\begin{array}{l}\text { Nilai } \\
\text { Indeks }\end{array}$ & $\begin{array}{l}\text { Nilai } \\
\text { Komposit }\end{array}$ \\
\hline 1. & $\begin{array}{l}\text { Metode penangkapan } \\
\text { ikan yang destruktif } \\
\text { dan/atau illegal }\end{array}$ & $\begin{array}{l}1=\text { frek. pelanggaran }>3 \mathrm{kasus} / \text { trip } \\
2=\text { frek. pelanggaran } 1-3 \mathrm{kasus} / \text { trip } \\
3=\text { frek. pelanggaran } 0 \mathrm{kasus} / \text { trip }\end{array}$ & 3 & 35,29 & 105,87 & 35,29 \\
\hline 2. & $\begin{array}{l}\text { Modifikasi } \quad \text { alat } \\
\text { penangkapan ikan dan } \\
\text { alat bantu penangkapan }\end{array}$ & $\begin{array}{l}1=>50 \% \text { ukuran target spesies }<\mathrm{Lm} \\
2=25-50 \% \text { ukuran target spesies }<\mathrm{Lm} \\
3=<25 \% \text { ukuran target spesies }<\mathrm{Lm}\end{array}$ & 1 & 29,41 & 29,41 & 9,8 \\
\hline 3. & $\begin{array}{l}\text { Kapasitas perikanan dan } \\
\text { upaya penangkapan }\end{array}$ & $\begin{aligned} & 1=\text { rasio }<1 \text { (overcapacity) } \\
2= & \text { rasio }=1 \\
3= & \text { rasio }>1 \text { (undercapacity) }\end{aligned}$ & 1 & 17,65 & 17,65 & 5,88 \\
\hline 4. & Selektivitas alat tangkap & $\begin{array}{l}1=\text { rendah }(<50 \% \text { alat tangkap selektif }) \\
2=\text { sedang }(50-75 \% \text { alat tangkap } \\
\text { selektif }) \\
3=\text { tinggi }(>75 \% \text { alat tangkap selektif })\end{array}$ & 3 & 17,65 & 52,95 & 17,65 \\
\hline
\end{tabular}


Tabel 7. Nilai komposit domain teknik penangkapan ikan EAFM perikanan tongkol krai di Perairan Bali Timur, Desa Seraya Timur, Karangasem.

\begin{tabular}{cccc}
\hline Domain & Nilai Komposit & Model Bendera & Deskripsi \\
\hline Teknik Penangkapan Ikan & 68,62 & & Baik \\
\hline
\end{tabular}

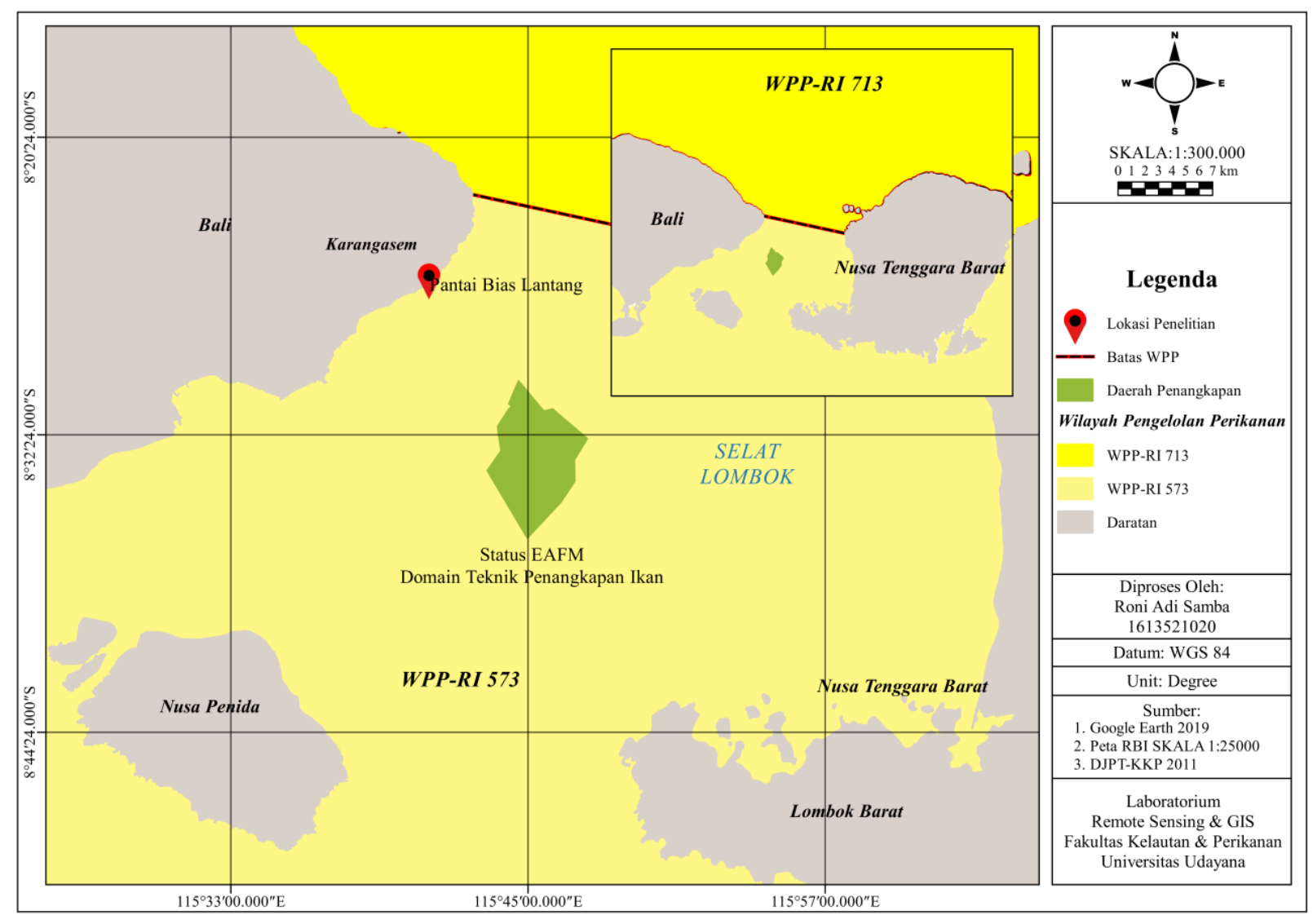

Gambar 7. Status EAFM Domain Teknik Penangkapan Ikan di Perairan Bali Timur, Desa Seraya Timur, Karangasem, Bali

Komoditas utama yang menjadi tangkapan nelayan di Desa Seraya Timur adalah jenis Ikan Tongkol Krai (Auxis thazard) yang termasuk ke dalam family Scombridae. Hasil observasi dan wawancara di lapangan menunjukan data produktivitas penangkapan (panen) ikan tongkol sejak tahun 2019 sudah terjadi sejak bulan Juli. Menurut nelayan setempat biasanya musim penangkapan (panen) terjadi pada bulan juni hingga september. Hal ini sejalan dengan Ilhamdi, (2016) yang menyatakan bahwa musim penangkapan ikan tongkol terjadi yaitu pada bulan Juli, Agustus, September, Oktober dan November. Meskipun demikian menurut nelayan setempat hasil tangkapan sejak tahun 2019. Sampai dengan penelitian ini dilakukan musim penangkapan ikan tongkol di Desa Seraya Timur hampir terjadi sepanjang tahun dan tentunya besar kecilnya perolehan hasil tangkapan dipengaruhi beberapa faktor, diantaranya penentuan fishing ground, jenis alat tangkap, ukuran kapal, dan cara pengoperasian alat tangkap.

Penjelasan diatas menunjukan bahwa pada kawasan perikanan tangkap tongkol skala kecil dewasa ini penting untuk dilaksanakan pengelolaan pemanfaatan sumber daya ikan yang berkelanjutan, sebagaimana diamanahkan di dalam UU No.45 Tahun 2009 tentang Perikanan yang dilakukan berdasarkan asas manfaat, keadilan, kemitraan, pemerataan, keterpaduan, keterbukaan, efisiensi, dan kelestarian yang berkelanjutan. Kompleksitasnya kepentingan dan pemanfaatan sumberdaya perikanan tersebut dirasakan sangat mendesak perlunya model/pendekatan kusudnya dalam pengelolaan perikanan tangkap di karangasem. Pendekatan yang paling mungkin dilakukan saat ini adalah Pengelolaan Perikanan Berpendekatan ekosistem atau EAFM. Hal ini sejalan dengan prinsip dasar FAO (2003), bahwa pengelolaan perikanan berkelanjutan perlu 
dilakukan guna menjamin kesehatan ekosistem, kesejahteraan pelaku perikanan, dan tata kelola yang harmonis.

\section{Penilaian indikator domain teknik penangkapan ikan di Desa Seraya Timur}

Pada penelitian ini penilaian status pengelolaan perikanan ikan tongkol di Desa Seraya Timur dilakukan dengan pendekatan EAFM yang terfokus pada domain teknik penangkapan ikan. Terdapat enam indikator pada domain teknik penangkapan ikan dari yaitu terdiri dari, (1) metode penangkapan ikan yang destruktif dan/atau illegal; (2) modifikasi alat penangkapan ikan dan alat bantu penangkapan; (3) kapasitas perikanan dan upaya penangkapan; (4) selektivitas penangkapan; (5) kesesuaian fungsi dan ukuran kapal penangkapan dengan dokumen legal, dan (6) sertifikasi awak kapal perikanan sesuai dengan peraturan. Akan tetapi pada penelitian ini hanya empat indikator yang digunakan. Mengingat lokasi perikanan tangkap di Desa Seraya Timur merupakan kategori perikanan skala kecil sehingga nelayan setempat tidak memiliki dokumen legal kapal serta tidak memerlukan sertifikasi awak kapal. Maka dua indikator (5 dan 6) pada EAFM domain teknik penangkapan ikan tersebut tidak dimasukkan dalam penilaian pada kegiatan penelitian ini.

Berdasarkan dengan undang - undang atau peraturan yang mengatur tentang nelayan kecil tidak diwajibkan memiliki dokumen perikanan yaitu UU Nomor 23 Tahun 2014 tentang Pemerintahan Daerah (selanjutnya disebut UU Pemerintahan Daerah), pada penjelasan Pasal 27 ayat 5 menjelaskan bahwa yang dimaksud dengan "nelayan kecil adalah nelayan masyarakat tradisional Indonesia yang menggunakan bahan dan alat penangkapan ikan secara tradisional, dan terhadapnya tidak dikenakan surat izin usaha dan bebas dari pajak, serta bebas menangkap ikan diseluruh pengelolaan perikanan dalam wilayah Republik Indonesia". Selain itu, dalam Peraturan Pemerintah Nomor 7 tahun 2000 tentang Kepelautan, pada Pasal 2 ayat 2 yang menjelaskan bahwa "kualifikasi keahlian dan keterampilan sebagaimana dimaksud dalam ayat 1 tidak berlaku terhadap pelaut yang bekerja pada kapal layer motor, kapal layar, kapal motor dengan ukuran kurang dari 3 - 5 GT, kapal pesiar pribadi yang dipergunakan tidak untuk berniaga dan kapal-kapal khusus".

\section{Indikator Metode Penangkapan Ikan yang Destruktif dan/atau Ilegal}

Berdasarkan hasil penilaian menunjukan bahwa indikator ini termasuk kategori hjau yaitu kondisi yang baik. Hal ini karena alat tangkap yang digunakan nelayan di Desa Seraya Timur bukan termasuk kategori destruktif dan bersifat ramah lingkungan. Alat yang digunakan ialah jaring insang dan juga pancing ulur. Kegiatan penangkapan yang illegal adalah penggunaan alat tangkap yang tidak sesuai dengan aturan dan tidak ramah lingkungan. Kegiatan penangkapan illegal tidak hanya berkaitan dengan alat tangkap yang destuktif saja, akan tetapi juga ditentukan oleh lokasi atau wilayah penangkapan itu sendiri. Hal ini dimaksudkan untuk tujuan tidak ada kegiatan penangkapan di daerah terlarang.

Daerah penangkapan yang menjadi tujuan fishing ground para nelayan di Desa Seraya Timur memiliki titik tidak tetap karena nelayan hanya menggunakan insting saat menentukan fishing ground-nya. Selain itu cuaca dan kondisi laut di perairan setempat juga menentukan jauh dekatnya lokasi penangkapan ikan. Dari hasil penelitian yang dilakukan oleh Sudarmo et al. (2010), bahwa beberapa faktor yang berperan nyata dalam mendorong pengambilan keputusan nelayan untuk memilih lokasi penangkapan ikan adalah cuaca dan kondisi laut. Berdasarkan hasil pemetaan daerah tangkapan nelayan dilapangan menunjukan bahwa lokasi fishing ground tidak termasuk dalam zona inti Kawasan Konservasi, sehingga zona yang dijadikan daerah tangkapan ikan adalah zona yang dapat dimanfaatkan hasil lautnya oleh nelayan setempat.

\section{Indikator Modifikasi Alat Penangkapan Ikan dan Alat Bantu Penangkapan}

Berdasarkan hasil penilaian pada indikator ini menunjukan warna merah yaitu kondisi yang buruk. Akan tetapi secara umum modifikasi alat tangkap yang dilakukan oleh nelayan di Desa Seraya Timur tidaklah berpengaruh terhadap keramah lingkungannya jaring insang itu sendiri, karena tidak adanya bahaya pada jaring insang permukaan dengan ukuran panjang 500 meter dan lebar 3 meter dengan ukuran lubang atau mesize 2 inchi. Selain jaring insang, permukaan atau gillnet nelayan setempat juga menggunnakan pancing ulur dimana memiliki konstruksi alat tangkap yang sesuai dengan Peraturan Pemerintah yang berlaku dan sesuai dengan Peraturan Menteri. Selain gillnet dan pancing ulur nelayan setempat juga tidak menggunakan alat bantu penangkapan lain seperti rumpon untuk menghadang ruaya gerombolan ikan.

Berdasarkan hasil pengamatan, Ikan tongkol krai (Auxis thazard) yang ditangkap oleh nelayan umumnya tidak memiliki perbedaan ukuran panjang yang signifikan. Berdasarkan hasil pengukuran yang telah dilakukan pada semua 
sample hasil tangkapan ikan selama periode penelitian diperoleh rata-rata panjang ikan hanya $25,3 \mathrm{~cm}$. Seluruh hasil tangkapan ikan yang dilakukan pengukuran memiliki panjang dibawah Lm ikan tongkol, sehingga jika mengacu pada penilaian EAFM pada Indikator Modifikasi Alat Penangkapan Ikan dan Alat Bantu Penangkapan hanya mendapat Skor 1. Hal ini dikarenakan hasil tangkapan nelayan tergolong masih kurang layak karena lebih dari 50\% ikan target yang diamati belum mencapai ukuran $L m$ nya yaitu $34,8 \mathrm{~cm}$ (Jayanti et al. 2020). Dari hasil pengukuran tersebut juga didapatkan tebal badan (body depth) dari ikan tongkol krai. Untuk ukuran ikan diatas $34,8 \mathrm{~cm}$ memiliki body depth sebesar 7,2-7,4 cm.

Mengingat hasil pengamatan menunjukan ukuran seluruh ikan hasil tangkapan yang diperoleh adalah berukuran dibawah $L m$. Maka penggunaan alat tangkap jaring insang dengan ukuran mesh size 2 inchi dan alat tangkap pancing ulur masih kurang layak untuk digunakan. Meskipun demikian, dalam melakukan kegiatan penangkapan ikan nelayan di Desa Seraya Timur tidak memakai alat bantu penangkapan seperti rumpon dan atau alat yang destruktif. Alat tangkap yang digunakan oleh nelayan sudah sesuai dengan peraturan yang ada. Selanjutnya perlu dilakukan modofikasi alat tangkap seperti memperbesar mesh size gillet menjadi 2,5 inchi. Hal ini perlu dilakukan karena penting untuk mengatur alat tangkap tersebut walaupun bersifat selektif, tetapi apabila menggunakan alat bantu dan juga memodifikasi tanpa memperhatikan peraturan yang ada akan membuat alat tangkap tersebut tidak efektif lagi dan bisa mengancam kelestarian sumberdaya ikan (Sulistyowati et al. 2018).

\section{Indikator Kapasitas Perikanan dan Upaya Penangkapan}

Pada indikator kapasitas perikanan (fishing capacity) dan upaya penangkapan secara tidak langsung dinilai dengan cara membandingkan fishing capacity pada tahun dasar (tahun sebelumnya) dengan fishing capacity pada tahun terakhir. Data yang digunakan untuk menghitung fishing capacity adalah jumlah hasil tangkapan ikan, jumlah kapal, dan jumlah trip (upaya penangkapan) dalam kurun waktur tertentu (data 6 tahun terakhir yaitu 2013 - 2018). Pada penilaian ini diperoleh rata - rata rasio 0,946 yang dimana angka ini menunjukan kondisi overcavacity dikarenakan rata-rata rasio yang didapatkan ialah $<1$. Hal ini sejalan dengan hasil penelitian yang dilakukan oleh Putra et al. (2020), bahwa kondisi tren CPUE perikanan tongkol cenderung menurun setiap tahunya. Kondisi trend CPUE yang menurun dapat memberikan indikasi bahwa kondi perikanan tersebut telah mengalami overcavacity, sehingga perlu dilakukannya kontrol terhadap upaya penangkapan guna menjaga keberlanjutan komoditas ikan Tongkol Krai di wilayah Perairan Desa Seraya Timur.

\section{Indikator Selektivitas Alat Tangkap}

Berdasarkan hasil perbandingan pada indikator selektivitas alat tangkap menggunakan analisis data dengan melihat hasil tangkapan dari operasi penangkapan. Proporsi hasil tangkapan utama dengan alat tangkap jaring insang, memperoleh persentase sebesar $100 \%$. Kemudian perbandingan proporsi hasil tangkapan utama menggunakan pancing ulur juga $100 \%$. Berdasarkan modul NWG EAFM, pada indikator ini diperoleh skor 3 dikarenakan tidak terdapat tangkapan sampingan (bycatch) pada alat tangkap jaring insang maupun pada pancing ulur. Alat tangkap jaring insang (gillnet) dan pancing ulur yang digunakan oleh nelayan termasuk alat tangkap yang selektif dan ramah lingkungan.

Berdasarkan hasil penelitian, komposisi hasil tangkapan utama dibandingkan hasil tangkapan sampingan adalah sebesar 100\%. Menurut Rofiqo et al. (2019) jika proporsi hasil tangkapan sasaran utama $>60 \%$ maka suatu alat tangkap dapat dikatakan ramah lingkungan. Alat tangkap jaring insang (gillnet) memiliki beberapa hal penting yang harus diperhatikan untuk memenuhi kriteria penangkapan ikan yang ramah lingkungan antara lain terdapat selektivitas terhadap ikan yang dijadikan target tangkapan atau ikan layak tangkap serta tidak menggunakan mesh size yang dilarang. Sumardi et al. (2014) menyatakan bahwa alat tangkap gillnet termasuk dalam alat tangkap yang pasif, ramah lingkungan serta selektif terhadap ikan target. Sedangkan pancing ulur tergolong alat tangkap yang selektif, ramah lingkungan dan mudah untuk dioperasikan (Sulistyaningsih et al. 2011).

\section{Penilaian status EAFM domain teknik penangkapan}

Berdasarkan hasil penilaian EAFM status domain teknik penangkapan ikan di perairan Desa Seraya Timur di peroleh nilai komposit dari pengelolaan perikanan tongkol krai adalah 68,62. Angka tersebut menunjukan hasil dengan deskripsi baik yaitu nilai komposit dengan warna flag modeling hijau muda. Namun dari hasil penilaian tersebut masih terdapat dua indikator yang berstatus buruk yaitu, indikator modifikasi alat tangkap dan indikator kapasitas perikanan tangkap (fishing cavacity). Hal ini dapat disebabkan pada penilaian indikator modifikasi alat tangkap $>50 \%$ 
hasil tangkapan ikan nelayan di Desa Seraya Timur berukuran dibawah $\mathrm{Lm}$. Nilai Kapasitas Perikanan dan Upaya Penangkapan menunjukan kondisi yang telah overcavacity.

Daerah penangkapan ikan di wilayah perairan Desa Seraya Timur termasuk kedalam kawasan WPP-RI 573. Berdasarkan penilaian status pada penelitian sebelumnya yang berlokasi di wilayah perairan Bali Timur pada kawasan WPP-RI 573 yang dilakukan oleh Pratama et al. (2020), menyatakan bahwa diwilayah perairan Bali Timur, Pantai Segara Kusamba diperoleh nilai komposit dari pengelolaan perikanan tongkol krai yaitu 80,4 dengan deskripsi baik sekali. Perbedaan hasil tersebut dapat disebabkan oleh kapasitas perikanan dan upaya penangkapan di kawasan tersebut masih dalam kondisi sangat baik, karena rata-rata nilai rasio yang didapatkan adalah $>1$ yaitu masih tergolong undercapacity.

\section{KESIMPULAN}

Penangkapan ikan di wilayah perairan Desa Seraya Timur termasuk kedalam kategori one day fishing dengan waktu keberangkatan pukul 04.00 09.00. Pola daerah tangkapan ikan yang terbentuk berada di wilayah perairan Bali Timur, Karangasem sampai ke Selat Lombok. Pola daerah penangkapan ikan yang terbentuk yaitu masih termasuk WPP 573. Hasil pengamatan menunjukan tangkapan tertinggi ditemukan pada pengamatan keempat, sedangkan yang terendah ditemukan pada trip ke enam. Pada pengamatan kedua, ketiga, kelima dan keenam memiliki jarak yang berdekatan.

Proses penangkapan yang dilakukan menggunakan jaring insang dan pancing ulur terdapat dua tahap yaitu setting dan hauling. Komoditas tangkapan utama nelayan adalah ikan tongkol krai (Auxis thazard) atau nelayan lokal menyebutnya dengan sebutan pindang awan. Penentuan daerah penangkapan ikan masih tergolong tradisional dengan menggunakan naluri dan pertimbangan dari pergerakan arah arus, angin dan pengalaman penangkapan sebelumnya.

Berdasarkan hasil penilaian EAFM status domain teknik penangkapan ikan di perairan Desa Seraya Timur mengindikasikan hasil yang baik dengan nilai komposit 68,62. Namun dari hasil penilaian tersebut masih terdapat dua indikator yang berstatus buruk. Hal ini disebabkan pada penilaian indikator modifikasi alat tangkap $>50 \%$ hasil tangkapan ikan nelayan di Desa Seraya Timur berukuran dibawah Lm. Dan pada indikator kapasitas perikanan dan upaya penangkapan menunjukan kondisi yang telah overcapacity.

\section{DAFTAR PUSTAKA}

[BPS] Badan Pusat Statistik Kabupaten Karangasem. 2016. Kabupaten Karangasem Dalam Angka 2015. Amlapura, Indonesia.

Direktorat Sumberdaya Ikan, Direktorat Jenderal Perikanan Tangkap, Kementrian Kelautan dan Perikanan, WWF-Indonesia dan Pusat Kajian Sumberdaya Pesisir dan Lautan Institut Pertanian Bogor. 2012. Modul Penilaian Performa Pengelolaan Perikanan menggunakan Indikator EAFM. Kajian Pilot Test ada Beberapa Jenis Perikanan di Indonesia.

[DKP] Dinas Kelautan dan Perikanan Kabupaten Karangasem. 2016. Jumlah Kelompok Nelayan Di Kabupaten

[DKP] Dinas Kelautan dan Perikanan Pemerintah Provinsi Bali. 2018. Statistik Perikanan Tangkap Provinsi Bali.

[FAO] Food and Agriculture Organization of United Nations. 2015. Small Scale and Artisanal Fisheries

Ilhamdi H, Telussa R, Ernaningsih D. 2016. Analisis tingkat pemanfaatan dan musim penangkapan ikan pelagis di Perairan Prigi Jawa Timur. Jurnal Ilmiah Satya Mina Bahari, 1(1): 52-64.

Imawati N. 2003. Studi Tentang Kepadatan Ikan Pelagis di Sekitar Rumpon di Perairan Pasauran, Banten [Skripsi]. Bogor: Institut Pertanian Bogor.

Jayanti NSRD. 2020. Profil aspek reproduksi ikan tongkol (Auxis Thazard) yang didaratkan di Pantai Segara Kusamba, Bali Pada Musim Barat [Skripsi]. Badung: Universitas Udayana.

[KKP-RI] Keputusan Menteri Kelautan Dan Perikanan Republik Indonesia Nomor Kep.06/Men/2010 Tentang Alat Penangkapan Ikan Di Wilayah Pengelolaan Perikanan Negara Republik Indonesia. Jakarta: Kementrian Kelautan dan Perikanan Republik Indonesia.

[KKP-RI] Kementrian Kelautan dan Perikanan Republik Indonesia. 2013. PERMEN KP No. 26/2013 tentang Usaha Perikanan Tangkap di Wilayah Pengelolaan Perikanan Negara Republik Indonesia. Jakarta: Kementrian Kelautan dan Perikanan Republik Indonesia.

[NWG EAFM] National Working Group on Ecosystem Approach to Fisheries Management. 2014. Modul Indikator Pengelolaan Perikanan dengan menggunakan Pendekatan EAFM (Ecosystem Approach to 
Fisheries Management). Jakarta: Direktorat Sumber Daya Ikan Kementerian Kelautan dan Perikanan Republik Indonesia.

Pratama IGABAP, Arthana IW, Pratiwi MA. 2020. Pendekatan Ekosistem pada Pengelolaan Perikanan Tongkol Skala Kecil Melalui Penilaian Domain Penangkapan Ikan di Perairan Kusamba Bali. Jurnal Pengelolaan Perikanan Tropis (Journal of Tropical Fisheries Management). 4(2): 38-48. https://doi.org/10.29244/jppt.v4i2.32772

Putra IPYP, Arthana IW, Pratiwi MA. 2020. Penilaian status domain sumber daya ikan berdasarkan pendekatan ekosistem untuk pengelolaan perikanan tongkol krai (Auxis thazard) di Perairan Selat Lombok yang Didaratkan di Desa Seraya Timur, Bali. Jurnal Pengelolaan Perikanan Tropis (Journal of Tropical Fisheries Management). 4(2): 29-37. https://doi.org/10.29244/jppt.v4i2.32770

Rofiqo IS, Zahidah, Kurniawati N, Dewanti LP. 2019. Tingkat keramahan lingkungan alat tangkap jaring insang (gillnet) terhadap hasil tangkapan ikan tongkol (Ethynnuss sp) di Perairan Pekalongan. Jurnal Perikanan dan Kelautan. 10(1): 64-69.

Sulistyaningsih RK, Barata A, Siregar K. 2011. Perikanan pancing ulur tuna di Kedonganan, Bali. Jurnal Penelitian perikanan Indonesia. 17(3): 185-191.

Sumardi Z, Sarong MA, Nasir M. 2014. Alat penangkapan ikan yang ramah lingkungan berbasis code of conduct for responsible fisheries di Kota Banda Aceh. Agrisep. 15(2): $10-18$. 